\title{
Fabrication of Calcium Phosphate Glass Using Eggshell and its Crystallization Behavior
}

\author{
Tea-Sung Kang* and Sang-Jin Lee ${ }^{*, * *, \dagger}$ \\ *Department of Advanced Materials Science and Engineering, Mokpo National University, Muan 58554, Korea \\ **Research Institute of Ceramic Industry and Technology, Mokpo National University, Muan 58554, Korea \\ (Received May 21, 2017; Revised August 2, 2017; Accepted August 21, 2017)
}

\begin{abstract}
The thermal properties and crystallization behavior of calcium phosphate glass fabricated using eggshell were examined. Nature eggshell has several impurities in the main component of $\mathrm{CaCO}_{3}$. To manufacture calcium phosphate glass, washed eggshell was dissolved in aqua-regia while adding a solution of isopropyl alcohol, D. I. water and phosphoric acid. The calcined precursor was melted at $1000^{\circ} \mathrm{C}$, and the glass $\left(\mathrm{T}_{\mathrm{g}}: 540^{\circ} \mathrm{C}\right)$ was crystallized at $620 \sim 640^{\circ} \mathrm{C}$, which temperature range is relatively low compared to the crystallization temperature of other general types of calcium phosphate glass. The calcium phosphate glass using eggshell was successfully crystallized without any additional nucleating agents due to the multiple effects of impurities such as $\mathrm{Fe}_{2} \mathrm{O}_{3}, \mathrm{Al}_{2} \mathrm{O}_{3}, \mathrm{SrO}$ and $\mathrm{SiO}_{2}$ in the eggshell. The main crystalline phase was $\beta$ - $\mathrm{Ca}\left(\mathrm{PO}_{3}\right)_{2}$ and a biocompatible material, hydroxyapatite, was also observed. The crystallization process was completed under the condition of a holding time of only $1 \mathrm{~h}$ at the low temperature.
\end{abstract}

Key words : Calcium phosphate glass, Glass ceramic, Crystallization, X-ray diffraction, Eggshell

\section{Introduction}

$\mathrm{P}$ hosphate glass has been steadily studied in the field of solid-state lasers because its light dispersion is lower but its refractive index is greater in comparison with those of silicate-based optical glass. $\left.{ }^{1-4}\right)$ In addition, phosphate glass is studied and applied in various fields including composite materials, sealing materials, medical materials, and solid electrodes because it has a low transition temperature, a low thermal expansion coefficient, and high chemical durability; also, its properties can be changed by adding a metal ion. ${ }^{5-10)}$

Various types of phosphate glass are available according to the composition. ${ }^{5-10)}$ Particularly, bioactive phosphate glass, which may be applied for medical purposes, is generally used as a filler for the treatment of osteoporosis or as a coating material for artificial bones, rather than as a main material because of its low mechanical properties. One typical bioactive phosphate glass is calcium phosphate glass, in which some of the phosphates are substituted with calcium (Ca). Calcium phosphate glass can usually be manufactured by melting or sol-gel methods. In a general melting method, frit is prepared and melted for molding in a graphite or steel mold; the molding product is finally crystallized through heat treatment. The sol-gel method enables more accurate control of the chemical composition than the melting

\footnotetext{
Corresponding author: Sang-Jin Lee

E-mail : lee@mokpo.ac.kr

Tel : +82-61-450-2493 Fax : +82-61-450-2498
}

method, and it is usually applied to the manufacturing of bioactive glass for special purposes. However, the sol-gel method has low productivity and high process cost than melting method. ${ }^{11)}$

Massera et $a l .{ }^{12)}$ studied the crystallization behavior of $50 \mathrm{P}_{2} \mathrm{O}_{5} \cdot(40-\mathrm{x}) \mathrm{CaO} \cdot \mathrm{xSrO} \cdot 10 \mathrm{Na}_{2} \mathrm{O}$ phosphate glass. Their results showed that the glass transition temperature and the crystallization temperature decreased as substitution with $\mathrm{SrO}$ increased, as the heating rate increased in the heat treatment for crystallization, and as the frit particle size decreased. Kasuga et al. ${ }^{13)}$ prepared a crystallization glass with the basic composition of $\mathrm{Ca} / \mathrm{P}=1\left(60 \mathrm{CaO} \cdot 30 \mathrm{P}_{2} \mathrm{O}_{5}\right.$ $\cdot 7 \mathrm{Na}_{2} \mathrm{O} \cdot 3 \mathrm{TiO}_{2}$ ) with the small amount of $\mathrm{Na}_{2} \mathrm{O}$ and $\mathrm{TiO}_{2}$, which are used as nucleating agents on the condition of different content; they also investigated the crystallization and sintering behavior and the fracture toughness of the prepared glass. The glass showed $\beta$-tricalcium phosphate (TCP) as the main crystalline phase through quenching process after melting at $1300^{\circ} \mathrm{C}$.

In this study, eggshells were used for the preparation of calcium phosphate glass. Eggshells contain not only calcium carbonate $\left(\mathrm{CaCO}_{3}\right)$ as the main ingredient but also various impurities as trace ingredients. Some of the natural impurities are assumed to play the role of nucleating agent for the crystallization of phosphate glass. Therefore, the possibility of performing the crystallization without the addition of a separate nucleating agent is examined, and the preparation conditions of the crystallization calcium phosphate glass from eggshells as well as the properties of the prepared glass are investigated. 


\section{Experimental Procedure}

The calcium phosphate glass was prepared by using eggshells as the starting material. After washing and the drying eggshells, the eggshell membrane was removed. Then, to dissolve $\mathrm{CaCO}_{3}$, the main ingredient of eggshells, the eggshells were added to a solution prepared by mixing aqua regia, isopropyl alcohol (IPA), and deionized water. When the dried eggshells were mixed with the solution, a strong exothermic reaction occurred, along with the discharge of a large amount of gas. After completing the dissolution of the eggshells (with no more bubble generation from the solution at room temperature), the undissolved eggshell membrane was removed. A phosphoric acid solution (85 wt\% in $\mathrm{H}_{2} \mathrm{O}$, DC Chemical Co. Ltd) was mixed with the prepared solution to induce a weight ratio of $\mathrm{CaO}$ to $\mathrm{P}_{2} \mathrm{O}_{5}$ of $4: 6$. An exothermic reaction also occurred in this stage. Transparent crystals were generated in the cooling process following the exothermic reaction.

The transparent crystals were completely dissolved at $150^{\circ} \mathrm{C}$ in the pre-drying of the solution prepared by mixing with the phosphoric acid solution. The pre-dried precursor was completely dried in a drying furnace at $200^{\circ} \mathrm{C}$ for $24 \mathrm{~h}$, and then calcined at $800^{\circ} \mathrm{C} 10^{\circ} \mathrm{C} / \mathrm{min}$ for $3 \mathrm{~h}$. The calcined precursors were put into an alumina crucible for melting at $1000^{\circ} \mathrm{C}$ for $3 \mathrm{~h}$. To complete the preparation of the phosphate glass for crystallization process, the melting product was quenched by pouring it into a stainless mold at room temperature. Subsequently, to investigate the crystallization behavior, heat treatment was performed by varying the temperature $\left(620^{\circ} \mathrm{C}\right.$ to $\left.640^{\circ} \mathrm{C}\right)$ and the holding time $(1 \mathrm{~h}$ to 6 h) based on thermal analysis data. The temperatureincrease rate was kept on $10^{\circ} \mathrm{C} / \mathrm{min}$ in all the heat treatment processes.

X-Ray fluorescence (XRF, VGB R-302 He, Beuth Verlag, Germany) analysis was performed to determine the composition of the starting material (eggshells) and the glass prepared using the starting material. X-Ray diffraction (XRD, X'pert-pro MPD, PANalytical, Netherlands) analysis was performed to analyze the crystal phases of the dried precursor, the calcined precursor, and the crystallized phosphate glass. The properties of the prepared phosphate glass were investigated through thermal analysis using a thermo-gravimetry analyzer/differential scanning calorimeter (TGA/ DSC, TG2171, Thermo Cahn Corp., USA).

\section{Results and Discussion}

Table 1 shows the composition of the eggshell starting material. Except for the organic materials, which cause ignition loss, the main composition was $\mathrm{CaCO}_{3}$, with various other components in small amounts.

A solution containing aqua regia was used to dissolve the eggshells. The following reactions occurred in the dissolution of the $\mathrm{CaCO}_{3}$ included in the eggshells:
Table 1. Composition of Raw Eggshell

\begin{tabular}{cc}
\hline Components & Amount (wt\%) \\
\hline $\mathrm{Na}_{2} \mathrm{O}$ & 0.435 \\
$\mathrm{MgO}$ & 0.2511 \\
$\mathrm{Al}_{2} \mathrm{O}_{3}$ & 0.061 \\
$\mathrm{SiO}_{2}$ & 0.165 \\
$\mathrm{P}_{2} \mathrm{O}_{5}$ & 0.02083 \\
$\mathrm{SO}_{3}$ & 0.6376 \\
$\mathrm{Cl}$ & 0.0256 \\
$\mathrm{~K}_{2} \mathrm{O}$ & 0.0823 \\
$\mathrm{CaCO}_{3}$ & 69.9101 \\
$\mathrm{Fe}_{2} \mathrm{O}_{3}$ & 0.0174 \\
$\mathrm{SrO}$ & 0.0443 \\
$\mathrm{Ig}$. loss & 28.34977 \\
\hline
\end{tabular}

$$
\begin{aligned}
& \mathrm{CaCO}_{3(\mathrm{~s})}+2 \mathrm{HCl}_{(\mathrm{I})} \rightarrow \mathrm{CaCl}_{2(\mathrm{a})}+\mathrm{H}_{2} \mathrm{O}_{(\mathrm{I})}+\mathrm{CO}_{2(\mathrm{~g})} \\
& \mathrm{CaCO}_{3(\mathrm{~s})}+2 \mathrm{HNO}_{3(\mathrm{a})} \rightarrow \mathrm{Ca}\left(\mathrm{NO}_{3}\right)_{2(\mathrm{a})}+\mathrm{H}_{2} \mathrm{O}_{(\mathrm{I})}+\mathrm{CO}_{2(\mathrm{~g})}
\end{aligned}
$$

The reaction was extremely strong exothermic and occurred with the production of yellow nitrosyl chloride (NOCl) gas with $\mathrm{CO}_{2}$. In addition, when the phosphoric acid solution was added to the prepared solution, an exothermic reaction occurred and transparent precipitates were produced by nitro-phosphate reaction. ${ }^{14-16)}$ The reactions that may have been involved in the process are as follows.

$$
\begin{aligned}
& \mathrm{CaCl}_{2(\mathrm{a})}+\mathrm{PO}_{4}^{-3} \text { (a) } \rightarrow \mathrm{CaHPO}_{4(\mathrm{a})}+\mathrm{Cl}_{2(\mathrm{~g})} \\
& \mathrm{Ca}\left(\mathrm{NO}_{3}\right)_{2(\mathrm{a})}+\mathrm{PO}_{4}^{-3}{ }_{(\mathrm{a})} \rightarrow \mathrm{CaHPO}_{4(\mathrm{a})}+\mathrm{O}_{2(\mathrm{~g})}+2 \mathrm{NO}_{2(\mathrm{~g})} \\
& 4 \mathrm{NO}_{(\mathrm{a})}+6 \mathrm{H}_{2} \mathrm{O} \rightarrow 4 \mathrm{NH}_{3(\mathrm{a})}+5 \mathrm{O}_{2(\mathrm{~g})} \\
& \mathrm{Ca}\left(\mathrm{NO}_{3}\right)_{2(\mathrm{a})}+4 \mathrm{H}_{3} \mathrm{PO}_{4(\mathrm{a})}+8 \mathrm{NH}_{3(\mathrm{a})} \rightarrow \\
& \quad \mathrm{CaHPO}_{4}+2 \mathrm{NH}_{4} \mathrm{NO}_{3(\mathrm{a})}+3\left(\mathrm{NH}_{4}\right)_{2} \mathrm{HPO}_{4(\mathrm{~s})}
\end{aligned}
$$

The product, assumed to be $\left(\mathrm{NH}_{4}\right)_{2} \mathrm{HPO}_{4}$, may have been decomposed to the production of the yellow gas $(\mathrm{NOCl})$ during the drying stage. ${ }^{15-16)}$

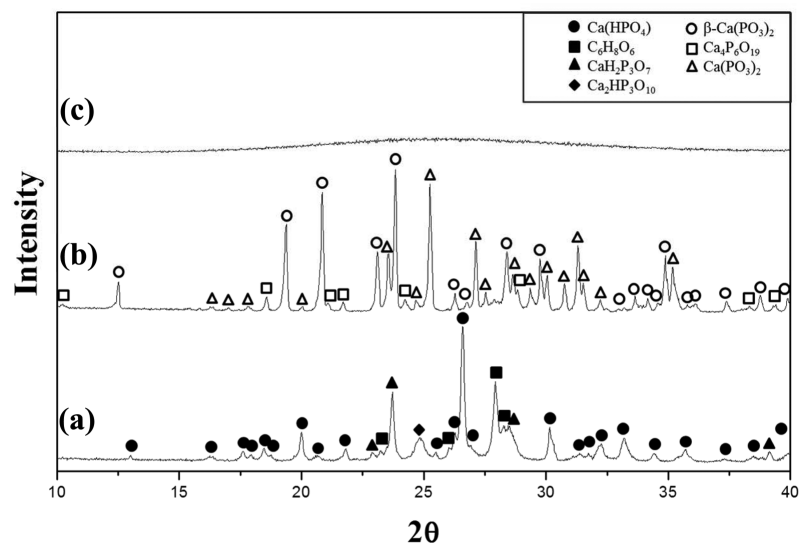

Fig. 1. XRD patterns of (a) dried precursor, (b) precursor calcined at $900^{\circ} \mathrm{C}$ for $3 \mathrm{~h}$ and (c) vitrified sample. 


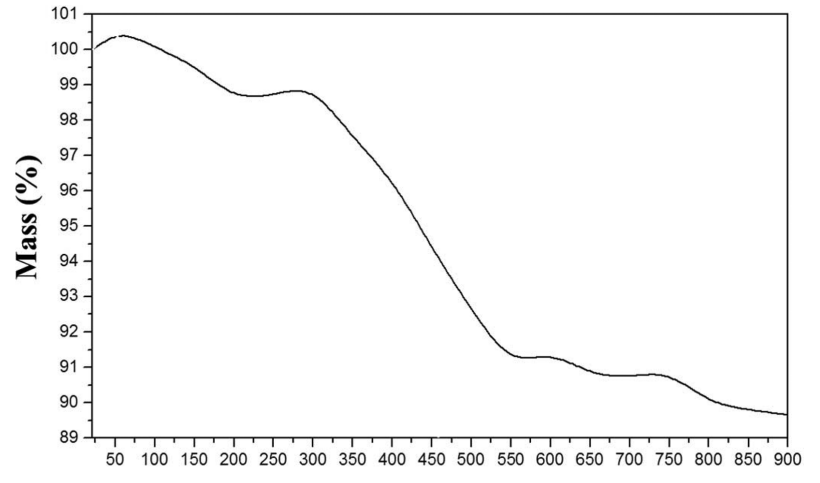

Temperature $\left({ }^{\circ} \mathrm{C}\right)$

Fig. 2. TGA results of dried precursor.

Figure 1 shows XRD patterns of the completely dried precursor, the precursor calcined at $800^{\circ} \mathrm{C}$, and the glass specimen prepared by melting the calcined precursor at $1000^{\circ} \mathrm{C}$. The precursor volume expanded more than three times during the calcination process. The volume expansion probably causes by the decomposition of the organic materials dissolved while the eggshells were dissolved in aqua regia. ${ }^{17)}$

The XRD pattern of the dried precursor (Fig. 1(a)) did not show the $\left(\mathrm{NH}_{4}\right)_{2} \mathrm{HPO}_{4}$ peaks and it can be assumed that $\left(\mathrm{NH}_{4}\right)_{2} \mathrm{HPO}_{4}$ have been decomposed in the drying process. $\left.{ }^{15}\right)$ Since ascorbic acid $\left(\mathrm{C}_{6} \mathrm{H}_{8} \mathrm{O}_{6}\right)$ was found in the dried precursor, some of the organic materials may have been dissolved together, and ascorbic acid is presumed to be a byproduct of the drying process. ${ }^{18)}$

Figure 2 shows the results of the TGA analysis that was performed to investigate the appropriate calcination temperature for the precursor. The weight slightly increased at the temperature below $100^{\circ} \mathrm{C}$ because the nitrate, that was not completely removed, may have absorbed the moisture in the air. The weight drastically decreased at $300^{\circ} \mathrm{C}$, which is the temperature matching with the decomposition tempera-
Table 2. XRF Data of Vitrified Sample

\begin{tabular}{|c|c|c|}
\hline \multirow{2}{*}{ Components } & \multicolumn{2}{|c|}{ Amount } \\
\hline & $\mathrm{wt} \%$ & mole \% \\
\hline $\mathrm{Na}_{2} \mathrm{O}$ & 0.0166 & 0.0282 \\
\hline $\mathrm{MgO}$ & 0.1655 & 0.4319 \\
\hline $\mathrm{Al}_{2} \mathrm{O}_{3}$ & 0.4489 & 0.4630 \\
\hline $\mathrm{SiO}_{2}$ & 0.0811 & 0.1420 \\
\hline $\mathrm{P}_{2} \mathrm{O}_{5}$ & 57.8175 & 21.4194 \\
\hline $\mathrm{K}_{2} \mathrm{O}$ & 0.0336 & 0.0375 \\
\hline $\mathrm{CaO}$ & 41.1701 & 77.2122 \\
\hline $\mathrm{Fe}_{2} \mathrm{O}_{3}$ & 0.0135 & 0.0089 \\
\hline $\mathrm{SrO}$ & 0.2532 & 0.2570 \\
\hline
\end{tabular}

ture of the ascorbic acid. ${ }^{19)}$

The calcined precursor was heat treated up to $800^{\circ} \mathrm{C}$ at which temperature almost no weight decrease occurred on the TGA data; the XRD results of the heat treated precursor (Fig. 1(b)) show no ascorbic acid peaks, indicating that the ascorbic acid was completely decomposed through the calcining process. The main crystal phases were found to be $\beta$ $\mathrm{Ca}\left(\mathrm{PO}_{3}\right)_{2}$ and $\mathrm{Ca}\left(\mathrm{PO}_{3}\right)_{2}$, and other calcium phosphate crystal phases were also found. The XRD pattern of the prepared glass specimen (Fig. 1(c)) showed typical amorphous phase.

Table 2 shows the chemical composition of the prepared glass specimen. The weight ratio of $\mathrm{CaO}$ to $\mathrm{P}_{2} \mathrm{O}_{5}$ was $4: 6$ in the batch composition, however the resulting ratio was 41 : 58 ratio, which is not matched with the batch composition, because the chemical composition of the natural eggshells (Table 1) was not uniform. In addition, the content of alumina was higher in the glass specimen than in the raw material eggshells, which may be because a part of the alumina crucible was melted out into the glass specimen in the melting process. The partially melting of the alumina crucible during the melting process has been mentioned in the

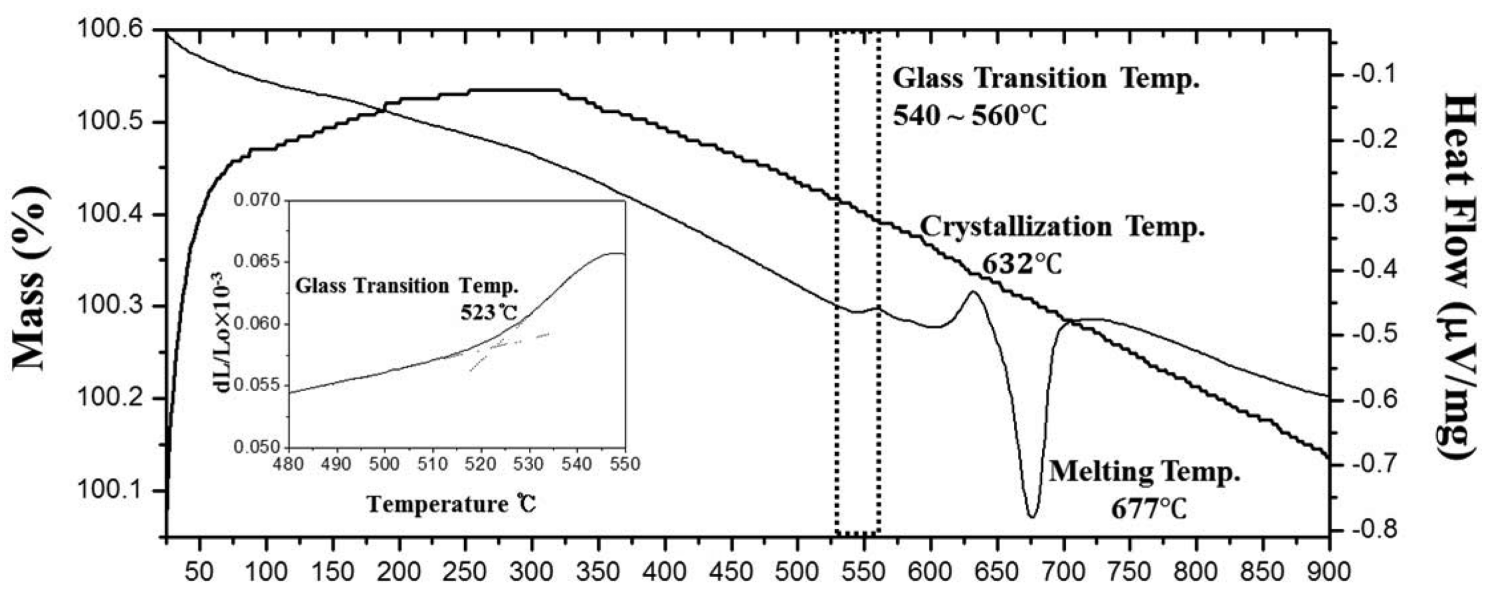

Temperature ${ }^{\circ} \mathrm{C}$

Fig. 3. TGA/DSC and TMA results of vitrified sample. 
report by Park et al. ${ }^{20)}$

Figure 3 shows the results of TGA/DSC and thermomechanical analyses (TMA) performed to investigate the thermal characteristics of the glass specimen. The TGA/DSC analysis showed that the glass transition temperature, crystallization temperature, and melting point were $540^{\circ} \mathrm{C}$ to $560^{\circ} \mathrm{C}, 630^{\circ} \mathrm{C}$, and $680^{\circ} \mathrm{C}$, however the TMA showed that the glass transition temperature was $520^{\circ} \mathrm{C}$, which was about $30^{\circ} \mathrm{C}$ lower than that value from the DSC results. This difference in the analytical results may be because of load applied to the specimen during the TMA. Zhang et al. ${ }^{21-22)}$ reported that if the $\mathrm{CaO} / \mathrm{P}_{2} \mathrm{O}_{5}$ molar ratio of a calcium phosphate glass is 1.2 or higher, the temperature for the formation of crystal phases in the calcium phosphate glass, as well as the melting point, increased due to an insufficiency of the glass-forming oxide of $\mathrm{P}_{2} \mathrm{O}_{5}$. Hence, additives such as a nucleating agent and a fusing agent are generally added at a ratio of 3 mole $\%$ or more in the preparation of calcium phosphate glass. However, in the composition of the calcium phosphate glass prepared in this study (Table 2), the $\mathrm{CaO} /$ $\mathrm{P}_{2} \mathrm{O}_{5}$ molar ratio was 3.6, which was much higher than that of other previous studies $\left(\mathrm{CaO} / \mathrm{P}_{2} \mathrm{O}_{5}=0.8\right.$ to 2.0$\left.)\right)^{12-13,20-23)}$ the melting point and the crystallization temperature in this study were considerably lower than the heat treatment temperatures in other reports (precursor melting temperature: $1200^{\circ} \mathrm{C}$ to $1400^{\circ} \mathrm{C}$, crystallization temperature: $800^{\circ} \mathrm{C}$ to $900^{\circ} \mathrm{C}$ ). This may be because of the many kinds of impurities included in the eggshells. The use of eggshells including $\mathrm{SrO}$ as an impurity might have been involved to a certain extent in the decrease of the crystallization temperature due to SrO acting as a nucleating agent, as mentioned in the introduction. ${ }^{12}$

To analyze the degree of crystallization depending on the holding time, Fig. 4 compares the XRD pattern of the glass specimen heat treated at $620^{\circ} \mathrm{C}$ for $1 \mathrm{~h}$ and that of the glass specimen heat treated at the same temperature for $6 \mathrm{~h}$. Although the crystallization occurred at $620^{\circ} \mathrm{C}$, the peak intensity was not significantly different between the specimen heat treated for 1 hour and the specimen heat treated for $6 \mathrm{~h}$. Crystallization occurred even without the addition

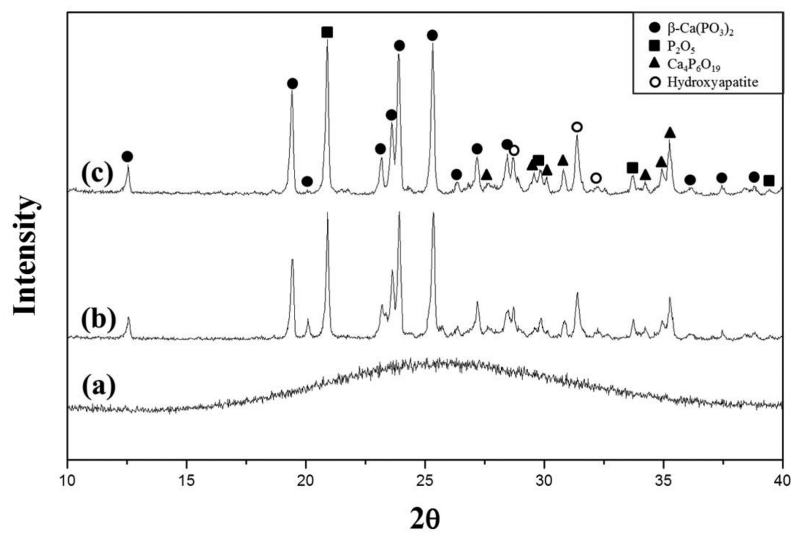

Fig. 4. XRD patterns of (a) vitrified sample, and heat-treated sample at (b) $620^{\circ} \mathrm{C}$ for $1 \mathrm{~h}$ and (c) $620^{\circ} \mathrm{C}$ for $6 \mathrm{~h}$.

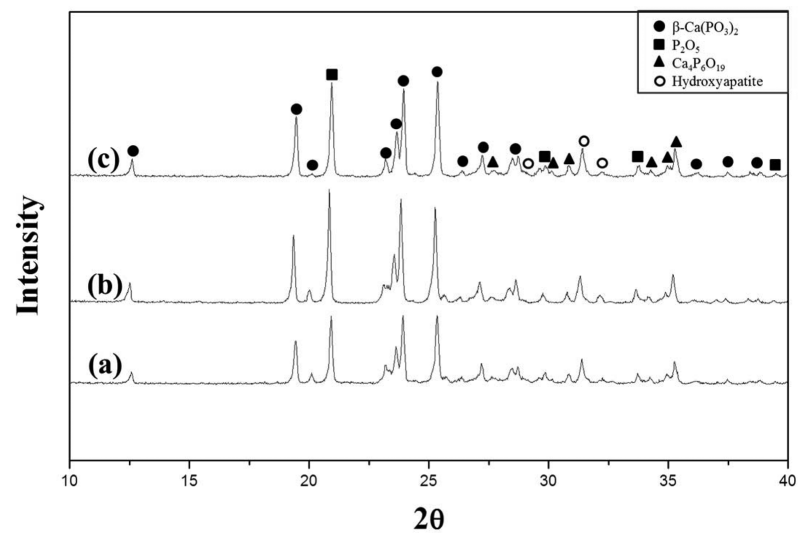

Fig. 5. XRD patterns of glass sample heat-treated for $1 \mathrm{~h}$ at each temperature of (a) $620^{\circ} \mathrm{C}$ (b) $630^{\circ} \mathrm{C}$ and (c) $640^{\circ} \mathrm{C}$.

of any nucleating agent, probably because the impurities found in the XRF analysis, except for $\mathrm{CaO}$ and $\mathrm{P}_{2} \mathrm{O}_{5}$, may have played the role of nucleating agents. Nan et $a .^{23)}$ reported that $\mathrm{Fe}_{2} \mathrm{O}_{3}, \mathrm{Al}_{2} \mathrm{O}_{3}$, and $\mathrm{SiO}_{2}$ affect the crystallization of calcium phosphate glass.

To investigate the degree of crystallization depending on the temperature, the specimens were heat treated for $1 \mathrm{~h}$ at temperatures in a range from $620^{\circ} \mathrm{C}$ to $640^{\circ} \mathrm{C}$, which was near the temperature of $630^{\circ} \mathrm{C}$ at which an exothermal peak was found in the DSC analysis. Fig. 5 shows the XRD patterns of the specimens. Swelling of the specimen surface occurred at temperatures higher than $650^{\circ} \mathrm{C}$; crystallization was not observed at a temperature lower than $610^{\circ} \mathrm{C}$. Therefore, the specimens heat treated at temperatures higher than $650^{\circ} \mathrm{C}$ and lower than $610^{\circ} \mathrm{C}$ were excluded from the XRD analysis. The results showed that the peak intensity increased as the heat treatment temperature increased. In addition, the peak intensity representing $\beta-\mathrm{Ca}\left(\mathrm{PO}_{3}\right)_{2}$ slightly increased. Fig. 6 provides images of the prepared calcium phosphate glass and the crystallized glass prepared by heat treatment at $640^{\circ} \mathrm{C}$ for $1 \mathrm{~h}$.

The results of the study showed that the calcium phosphate glass prepared using eggshells was easily crystallized. Also glass transition temperature, crystallization tempera-

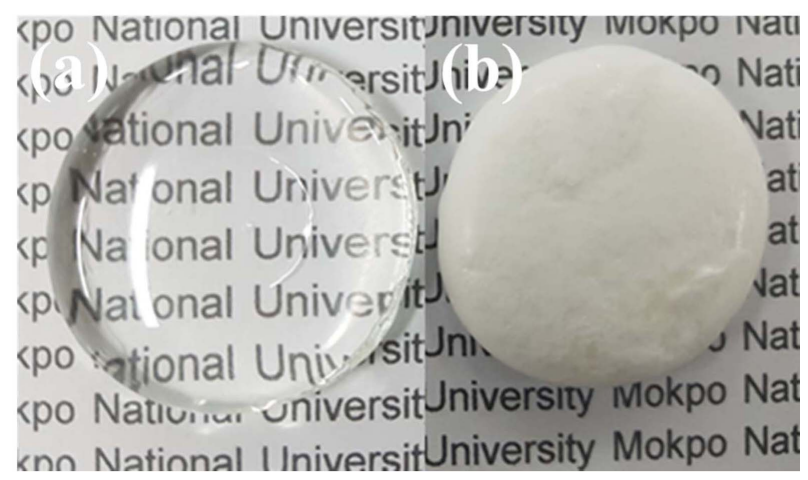

Fig. 6. Photographs of (a) glass sample and (b) glass ceramic sample heat treated at $640^{\circ} \mathrm{C}$ for $1 \mathrm{~h}$. 
ture, and melting point were lower than other studies even it has high $\mathrm{CaO} / \mathrm{P}_{2} \mathrm{O}_{5}$ molar ratio. By controlling the amount of phosphoric acid addition, and performing a biocompatibility test with the glass samples, further studies will be conducted to investigate the formation of biocompatible crystal phases in calcium phosphate glass depending on the ratio of $\mathrm{CaO}$ to $\mathrm{P}_{2} \mathrm{O}_{5}$ in the composition.

\section{Conclusions}

Calcium phosphate glass was prepared by dissolving eggshells in aqua regia and adding phosphoric acid. All organic byproducts were removed in the preparation process. Many calcium phosphate crystal phases were found in the precursor, the calcined precursor, and the crystallized specimen. Although in comparison with other calcium phosphate glass products, the $\mathrm{CaO} / \mathrm{P}_{2} \mathrm{O}_{5}$ molar ratio was very high in the calcium phosphate glass prepared using eggshells, crystallization occurred due to the impurities included in the eggshells even in the absence of an added nucleating agent. The degree of crystallization of the calcium phosphate glass prepared using eggshells was affected more by the heat treatment temperature than by the holding time. The glass transition and the crystallization temperature were much lower in this study, than those temperatures as determined in previous studies conducted using commercially available products as $\mathrm{CaO}$ source.

\section{REFERENCES}

1. N. J. Kreidl and W. A. Weyl, "Phosphates in Ceramic Ware: IV, Phosphate Glasses," J. Am. Ceram. Soc., 24 [11] 372-78 (1941).

2. B. Hans and N. Norbert, The Properties of Optical Glass; $1^{\text {st }}$ ed., pp. 387-91, Springer, Berlin, 1968.

3. M. J. Weber, "Science and Technology of LASER Glass," J. Non-Cryst. Solids, 123 [1-3] 208-22 (1990).

4. J. H. Campbell, "Damage Resistant Optical Glasses for High Power Lasers-A Continuing Glass Science and Technology Challenge," Glass Sci. Technol., 75 91-108 (2004).

5. R. K. Brow, L. Kovacic, and R. E. Loehman, "Novel Glass Sealing Technologies," Ceram. Trans., 70 177-88 (1996).

6. C. J. Quinn, G. H. Bell, and J. E. Dickinson, "Alkali Zinc Pyrophosphate Glasses for Polymer Blends," Int. Congr. Glass, 16 79-82 (1992).

7. D. E. Day, Z. Wu, C. S. Ray, and P. Hrma, "Chemically Durable Iron Phosphate Glass Waste Forms," J. NonCryst. Solids, 241 [1] 1-12 (1998).

8. J. Vogel, P. Wange, and P. Hartmann, "Effect of Composition Changes on the Structure and Properties of Phosphate Glasses in the Pyrophosphate Region," Glass Sci.
Tech., 70 [1] 23-7 (1997).

9. J. Fu, "Fast $\mathrm{Li}^{+}$ion Conduction in $\mathrm{Li}_{2} \mathrm{O}-\left(\mathrm{Al}_{2} \mathrm{O}_{3} \mathrm{Ga}_{22} \mathrm{O}_{3}\right)$ $\mathrm{TiO}_{2}-\mathrm{P}_{2} \mathrm{O}_{5}$ Glass Ceramics," J. Mater. Sci., 33 [6] 1549-53 (1998).

10. J. B. Bates, N. J. Dudney, G. R. Gruzalski, R. A. Zuhr, A. Choudhury, C. F. Luck, and J. D. Robertson, "Electrical Properties of Amorphous Lithium Electrolyte Thin Films," Solid State Ionics, 53 647-54 (1992).

11. A. R. Boccaccini, D. S. Brauer, and L. Hupa, Bioactive Glasses Fundamentals: Technology and Applications; pp. 27-9, The Royal Society of Chemistry, United Kingdom, 2016.

12. J. Massera, M. Maryran, J. Rocherullé, and L. Hupa, "Crystallization Behavior of Phosphate Glasses and Its Impact on the Glasses Bioactivity," J. Mater. Sci., 50 [8] 3061-102 (2015).

13. T. Kasuga and Y. Abe, "Novel Calcium Phosphate Ceramics Prepared by Powder Sintering and Crystallization of Glasses in the Pyrophosphate Region,” J. Mater. Res., 3 [12] 3357-60 (1998).

14. J. Stee, H. Aasum, and T. Heggeboe, Manual of Fertilizer Processing; pp. 393-420, CRC Press, New York, 1986.

15. J. R. V. Wazer, Phosphorus and Its Compounds; Vol. 1, pp. 503, Interscience, New York, 1958.

16. J. Jr. McKetta and W. A. Cunningham, Encyclopedia of Chemical Processing and Design Vol. 35 (Chemical Processing and Design Encyclopedia); pp. 478, Marcel Dekker Inc., New York, 1990.

17. S. J. Lee and J. W. Kim, "Characteristics of Nickel Aluminate Ceramics Synthesized by Organic(PVA)-Inorganic Solution Technique," J. Korean Ceram. Soc., 40 [7] 690-95 (2003).

18. C. H. Lee, P. A. Seib, R. C. Hoseney, and C. W. Deyoe, "Chemical Synthesis of Several Phosphoric Esters of Lascorbic Acid," Carbohydr. Res., 67 [1] 127-38 (1978).

19. G. Vernin, S. Chakib, S. M. Rogacheva, T. D. Obretenov, and C. Párkányi, "Thermal Decomposition of Ascorbic Acid," Carbohydr. Res., 305 [1] 1-15 (1997).

20. Y. W. Park, B. S. Hyun, and T. H. Kim, "A Study on the Porous Glass-Ceramics in the Phosphate System," J. Korean Ceram. Soc., 32 [7] 858-64 (1995).

21. Y. Zhang and J. D. Santos, "Microstructural Characterization and in Vitro Apatite Formation in $\mathrm{CaO}-\mathrm{P}_{2} \mathrm{O}_{5}-\mathrm{TiO}_{2}$ MgO- $\mathrm{Na}_{2} \mathrm{O}$ Glass-Ceramics," J. Eur. Ceram. Soc., 21 [2] 169-75 (2001).

22. Y. Zhang and J. D. Santos, "Crystallization and Microstructure Analysis of Calcium Phosphate-Based Glass Ceramics for Biomedical Applications," J. Non-Cryst. Sol$i d s, 272$ [1] 14-21 (2000).

23. Y. Nan, W. E. Lee, and P. F. James, "Crystallization Behavior of CaO- $\mathrm{P}_{2} \mathrm{O}_{5}$ Glass with $\mathrm{TiO}_{2}, \mathrm{SiO}_{2}$, and $\mathrm{Al}_{2} \mathrm{O}_{3}$ Additions," J. Am. Ceram. Soc., 75 [6] 1641-47 (1992). 